\section{Field Resistance to Bemisia tabaci in Cucumis melo}

\author{
N. Boissot ${ }^{1}$, D. Lafortune, C. Pavis, and N. Sauvion \\ Unitéde Recherches en Productions Végétales, Institut National de la Recherche \\ Agronomique, 97170 Petit-Bourg, French West Indies
}

Additional index words. melon, whitefly, insect resistance

\begin{abstract}
The whitefly Bemisia tabaci (Gennadius) B-Biotype is a major pest on cucurbits in the Caribbean islands. Five field trials were conducted to identify resistance among 80 genotypes of Cucumis melo $\mathrm{L}$. from diverse geographic origins. We focused on resistant rather than tolerant genotypes by counting adults on the abaxial side of two leaves of each plant at least three times in each trial, and larval density of under leaf disk samples at least twice in each trial. On the basis of insect density, three Indian accessions, PI 414723, PI 164723, and 90625, and one Korean accession, PI 161375, had field resistance. On those accessions, we observed 3.6 to 6 times fewer adults than on the most susceptible genotypes ('AR Top Mark' or 'Délice de Table') and 11 to 29 times fewer larvae than on 'AR Top Mark' or B66-5. Those levels of resistance may be sufficient to significantly reduce pesticide use in Guadeloupe (Lesser Antilles) where $B$. tabaci populations are lower than in the Southern United States or in the Mediterranean Basin. Higher levels of resistance are needed for genetic control, and may be achieved by a combination of different partial resistance genes.
\end{abstract}

Although sugarcane (Saccharum L.) and banana (Musa L.) remain the main crops in the West Indies, the production of fruits, vegetables, and flowers is increasing in economic importance. Among those crops, melon $(\mathrm{Cu}$ cumis melo L.) is the most important export in the French West Indies. Insects are the key pest of melon culture in the French West Indies (Boissot et al., 2000). Moreover, Bemisia tabaci Gennadius (Hemiptera: Aleyrodidae) is considered a major pest in all the West Indies (Paul, 1999). Bemisia tabaci causes economic damage in melon and other cucurbit species, such as zucchini (Cucurbita pepo L.), squash (Cucurbita moschata L.), and cucumber (Cucumis sativus L.). Bemisia tabaci has been reported since 1936 in Puerto Rico, Greater Antilles (Bird, 1998), and 1969 in Guadeloupe, Lesser Antilles (Etienne et al., 1991). The B-biotype, that causes leaf silvering in Cucurbita, probably appeared at the end of the 1980's in the Caribbean islands (Bird and Brown, 1998). It was described in Jamaica (Brown et al, 1998), the Dominican Republic (Tappertzhofen, 1996), Puerto Rico (Bird and Brown, 1998), Guadeloupe, and Martinique (Sauvion et al., 1998). The B-biotype is an efficient virus vector, but no viruses transmitted by $B$. tabaci have been described in cucurbits in the Caribbean islands. In Cucumis, the insect affects the yield: populations of 2.6 larvae per $10 \mathrm{~cm}^{2}$ leaf or six adults per leaf decreased melon yield as much as $30 \%$ (Riley

Received for publication 28 Sept. 2001. Accepted for publication 7 Mar. 2002. We wish to thank Franck Sapotille, Hughes Poitout, and the staff of the experimental unit of Godet, INRA (Avignon, France), for their technical assistance. We thank Catherine Dogimont for critically reviewing the manuscript. ${ }^{1}$ To whom reprint requests should be addressed. E-mail address: boissot@antilles.inra.fr and Palumbo, 1995). Whiteflies also excrete honeydew on the leaves and the fruits, which serves as a growth medium for smooty mold. To control the whiteflies, frequent insecticide applications are necessary and imacloprid (Confidor; Bayer, Puteaux, France) was commonly used in the French West Indies. This chemical is no longer allowed on cucurbits crops in the French territories because of its toxicity against bees. Other control strategies are needed for whiteflies. Biological control was not sufficient to reduce $B$. tabaci populations in Cucurbits (Sauvion et al., 2000). The development of resistant cultivars is one of the most promising approaches (Wiseman, 1994).

In 1987, C.melo resistance to B.tabaci was studied in California prior to the emergence of B-biotype (Kishaba et al., 1992). Half of the number of adults were counted on the cultivar 'WMR 29' as on the accession PI 414723, but stunting was similar on both genotypes. Starting in 1993, McCreight screened more than 500 genotypes under natural infestation in California where the B-biotype has overcome the A-biotype (McCreight, 1993, 1994, 1995). The scoring rated the vigor of the plants and some genotypes appeared partially tolerant according to that criterion. Simmons and McCreight (1996) then compared infested and uninfested plants. They observed a high correlation between the number of immatures on the leaves and the reduction of the leaf surface and the dry biomass. Nevertheless, the number of immatures did not vary between the tested genotypes. Studies were also performed in Spain, where the B- and Q-biotypes of B. tabaci are present. During a screening conducted under a naturally infested (B-biotype) greenhouse, Moreno et al. (1993) observed fewer adults and eggs on the Far Eastern Asian accession CuM 190 = 'Kanro Makuwa' than on muskmelon genotypes. Soria et al. (1999), using a no-choice test and a free-choice test with controlled infestation, confirmed that 'Kanro Makuwa' was partially resistant and identified TGR-1551, from Zimbabwe, as another partially resistant accession. In spite of those studies, the identification of cultivars with significant level of field resistance has been unsuccessful.

The objective of this study was to identify field resistance sources. We screened $C$. melo for resistance against B-B. tabaci in naturally infected fields in the French West Indies. Because screenings based on the plant vigor in field trials were disappointing for $B$. tabaci resistance, we focused on the density of the adult and larval insect.

\section{Materials and Methods}

Field tests. Five trials, called 97-1, 97-2, 98-1,98-2, and 99, were conducted from 1997 to 1999 . Seeds of melon were sown in $60-\mathrm{mL}$ pots filled with disinfected soil in a greenhouse at the Institut National de la Recherche Agronomique (INRA) Center in Petit-Bourg, Guadeloupe, French West Indies. Seedlings were transplanted in the field on a black plastic mulch, 14 to $22 \mathrm{~d}$ later depending on the trials. The distance between rows was $2 \mathrm{~m}$ with $1 \mathrm{~m}$ between plants. In 97-1, five plants were transplanted per plot and 5 replications were present [in a completely randomized design (CRD)]. For the four other trials, each plot consisted of four plants with four replications (also in CRD). All trials were drip irrigated. Fungicides (bupirimate and chorothalonil) were applied every 2 weeks to control powdery mildew (Sphaerotheca fulginea Schlecht. ex Fr. and Erysiphe cichoracearum DC ex Merat) and downy mildew (Pseudoperonospora cubensis Berk. and M.A. Curtis). The first spray was applied 1week after transplanting in 97-1 and 99, 2 weeks after transplanting in 97-2, and in both 1998 trials. Pyrethrinoids were used against melonworms (Diaphania hyalinata L.) every 2 weeks after transplanting. The first spray was applied 1 week after transplanting in the 97-2 and 98-1 trials, 2 weeks after transplanting in the $97-1$ and 99 trials, and 4 weeks after transplanting in the 98-2 trial. The trials were transplanted on $27 \mathrm{Feb}$. and 23 May 1997, on 27 Jan. and 28 Apr. 1998, and on 20 Apr. 1999, at the INRA Field Station, Godet, Petit-Canal, Guadeloupe. The site has clay swelling soil, the average annual rainfall is $1600 \mathrm{~mm}$ and the annual potential evapotranspiration is $1500 \mathrm{~mm}$.

Depending of timing of infestation, initiation of counts varied for each trial. One hour after the sunrise, adults were counted weekly, on the abaxial surface of the third apical leaf of two stems of each plant. Adults were counted from 2 to 8 weeks after transplanting in 1997 , from 3 to 5 weeks after transplanting in the 1998 trials, and from 2 to 5 weeks after transplanting in the 1999 trial. The third leaf of a randomly chosen stem of each plant was tagged 3 to 8 weeks after transplanting in the 97-2 trial and 4 to 7 weeks after transplanting in 1998 and 1999. Two weeks later, a leaf disk of 2.22 $\mathrm{cm}^{2}$ was removed and taken to the laboratory. The larvae were counted under a binocular 
microscope $(\times 12)$. For each plant, the sum of observed adults and the sum of sampled larvae were calculated. The means per plot, in each trial, were then calculated and used to classify the genotypes on the basis of the average rankings. The genotype effects were tested using the nonparametric Kruskal and Wallis tests on Systat software (SPPS, 1998).

Eighty genotypes were evaluated (Tables 1 and 2). Some genotypes that were promising in the first trials were re-evaluated. The seeds were obtained from Dr. C. Dogimont and Dr. M. Pitrat of the INRA, Avignon, France.

\section{Results and Discussion}

Adults and larvae both cause damage to plants. An average infestation of $>2.6$ larvae per $10 \mathrm{~cm}^{2}$ (threshold for $30 \%$ yield loss) was observed in our five field trials. Nevertheless, because $<6$ adults per leaf were observed on average in the 97-1, 98-1, and 99 trials, we considered that low infestation occurred in those trials. At the other extreme, we observed an average of $>10$ adults per leaf during the 97-2 and 98-2 trials: a high $B$. tabaci infestation occurred in those two trials. We observed

Table 1. Average ranking and maximum of number of B. tabaci observed on genotypes of C. melo in Guadeloupe [French West Indies] during low infestation. Ranking = average ranking of $\sum$ adults and $\sum$ larvae, $\mathrm{N}=$ number of observations, $\mathrm{df}=$ degree of freedom, $\mathrm{KW}=\mathrm{Kruskal}$ and Wallis statistic for genotype effect; Max = maximum of adults observed under 2 leaves and larvae under 2.22- $\mathrm{cm}^{2}$ leaf disk.

\begin{tabular}{|c|c|c|c|c|c|c|c|c|c|}
\hline \multirow[b]{3}{*}{ Genotype } & \multirow[b]{3}{*}{ Source } & \multirow{2}{*}{\multicolumn{2}{|c|}{$\frac{97-1 \text { (5 replicates) }}{\text { Adults }}$}} & \multicolumn{4}{|c|}{ 98-1 (4 replicates) } & \multirow{2}{*}{\multicolumn{2}{|c|}{$\begin{array}{c}99 \text { (4 replicates) } \\
\text { Adults } \\
\end{array}$}} \\
\hline & & & & \multicolumn{2}{|c|}{ Adults } & \multicolumn{2}{|c|}{ Larvae } & & \\
\hline & & Ranking & $\overline{\operatorname{Max}}$ & Ranking & $\overline{\operatorname{Max}}$ & Ranking & Max & Ranking & Max \\
\hline & & \multicolumn{2}{|c|}{$\begin{array}{l}\mathrm{N}=76, \mathrm{df}=16 \\
\mathrm{KW}=40.5\end{array}$} & \multicolumn{2}{|c|}{$\begin{array}{l}\mathrm{N}=90, \mathrm{df}=22 \\
\mathrm{KW}=41.1\end{array}$} & \multicolumn{2}{|c|}{$\begin{array}{l}\mathrm{N}=88, \mathrm{df}=22 \\
\mathrm{KW}=60.4\end{array}$} & \multicolumn{2}{|c|}{$\begin{array}{l}\mathrm{N}=115, \mathrm{df}=28 \\
\mathrm{KW}=62.2\end{array}$} \\
\hline 72025 & Antilles & 37.7 & 68 & --- & $\overline{---}$ & -- & --- & --- & --- \\
\hline 90625 & PI 313970 & --- & --- & 16.6 & 5 & 13.7 & 7 & --- & --- \\
\hline Anso Al 77 & Spain & --- & --- & --- & --- & --- & --- & 41.5 & 4 \\
\hline Aodaisimouri & Japan & --- & --- & --- & --- & --- & --- & 38.5 & 6 \\
\hline AR PMR5 & United States & --- & --- & 52 & 9 & 75.7 & 41 & --- & --- \\
\hline Chengam & --- & --- & & 40.6 & 5 & 20.2 & 7 & --- & --- \\
\hline Concombre chien & Antilles & 8.1 & 10 & --- & --- & --- & --- & 9.6 & 2 \\
\hline Durgapura madhu 1 & India & --- & --- & 67.9 & 19 & 80.6 & 127 & --- & --- \\
\hline Edisto 47 & United States & 46.3 & 38 & --- & --- & --- & --- & --- & --- \\
\hline Exel & France & 35.7 & 24 & --- & --- & --- & --- & --- & --- \\
\hline Faizabadi Phoont & India & --- & --- & 36.2 & 9 & 13.5 & 8 & --- & --- \\
\hline Fegouss1 & --- & --- & --- & --- & --- & --- & --- & 64.5 & 11 \\
\hline Freeman's Cucumber & Japan & --- & --- & 36 & 14 & 40.2 & 21 & --- & --- \\
\hline Gasankalinskaja & Russia & --- & --- & --- & --- & --- & --- & 82.4 & 10 \\
\hline Ginsen Makuwa & Japan & --- & --- & 36.4 & 11 & 42.8 & 12 & --- & --- \\
\hline Humaïd tendelti & Sudan & 30.7 & 18 & --- & --- & --- & --- & 64.3 & 6 \\
\hline Iran $\mathrm{H}$ & Iran & 50.4 & 36 & --- & --- & --- & --- & --- & --- \\
\hline К 5442 & China & --- & --- & 36.9 & 13 & 40.9 & 19 & 14.6 & 3 \\
\hline Kanro Makuwa & Japan & --- & --- & 31.4 & 6 & 49.7 & 22 & --- & --- \\
\hline Kogane 9 Go Makuwa & Japan & --- & --- & --- & --- & --- & --- & 47.4 & 6 \\
\hline Mainstream & United States & --- & --- & --- & --- & --- & --- & 84.6 & 11 \\
\hline Margot & France & 44.8 & 18 & --- & --- & --- & --- & --- & --- \\
\hline Meloncillo & Colombia & --- & --- & --- & --- & --- & --- & 25.2 & 4 \\
\hline MR 1 & India & 57.8 & 32 & --- & --- & --- & --- & --- & --- \\
\hline Nantais Oblong & France & 39.5 & 16 & --- & --- & --- & --- & --- & --- \\
\hline Ogon 9 & Japan & --- & --- & 34 & 10 & 36.6 & 13 & 24.9 & 5 \\
\hline Oogon Makuwa & Japan & --- & --- & 36.5 & 7 & 26.7 & 15 & 28.8 & 3 \\
\hline Ouzbèque 2 & Uzbekistan & 71 & 36 & --- & --- & --- & --- & --- & --- \\
\hline Perlicha & Antilles & 48.5 & 92 & --- & --- & --- & --- & --- & --- \\
\hline Perlita & United States & --- & --- & 48.7 & 10 & 47.4 & 39 & --- & --- \\
\hline Persiki BR5 & Yugoslavia & --- & --- & 57.4 & 15 & 64.1 & 36 & --- & --- \\
\hline PI 124112 & India & --- & --- & 54.5 & 9 & 53.4 & 25 & --- & --- \\
\hline PI 124440 & India & --- & --- & 80.9 & 25 & 67.5 & 56 & 71.3 & 10 \\
\hline PI 140471 & Unclear & --- & --- & 26.6 & 8 & 34.6 & 13 & 27.9 & 5 \\
\hline PI 161375 & Korea & 13.9 & 8 & --- & --- & --- & --- & --- & --- \\
\hline PI 164320 & India & --- & --- & --- & --- & --- & --- & 34.4 & 5 \\
\hline PI 167266 & Turkey? & --- & --- & --- & --- & --- & --- & 73.1 & 7 \\
\hline PI 167487 & --- & --- & --- & 76.5 & 20 & 76.7 & 64 & --- & --- \\
\hline PI 177362 & Turkey & --- & --- & --- & --- & --- & --- & 66.9 & 10 \\
\hline PI 179248 & Turkey & --- & --- & --- & --- & --- & --- & 83.5 & 10 \\
\hline PI 179905 & India & --- & --- & --- & --- & --- & --- & 64.4 & 8 \\
\hline PI 183311 & --- & --- & --- & 29 & 5 & 26.9 & 16 & --- & --- \\
\hline PI 183675 & Turkey & --- & --- & --- & --- & --- & --- & 103.6 & 11 \\
\hline PI 224770 & India & --- & --- & --- & --- & --- & --- & 87.1 & 7 \\
\hline PI 237257 & Turkey & --- & --- & --- & --- & --- & --- & 82.8 & 13 \\
\hline PI 255478 & Korea & --- & --- & 46 & 11 & 15 & 6 & --- & --- \\
\hline PI 273438 & Switzerland & --- & --- & --- & --- & --- & --- & 89.4 & 7 \\
\hline PI 282448 & S. Africa & --- & --- & --- & --- & --- & --- & 63.3 & 7 \\
\hline PI 313970 & India & --- & --- & --- & --- & --- & --- & 49.8 & 7 \\
\hline PI 344342 & Turkey & --- & --- & --- & --- & --- & --- & 39.6 & 5 \\
\hline PI 414723 & India & 8 & 6 & 17.6 & 7 & 16 & 8 & --- & --- \\
\hline PI 532841 & --- & --- & --- & --- & --- & --- & --- & 64.9 & 9 \\
\hline Pillnitzer Zuker & Europe & --- & --- & --- & --- & --- & --- & 74 & 7 \\
\hline PMR 5 & United States & 45.4 & 16 & --- & --- & --- & --- & --- & --- \\
\hline Top Mark & United States & --- & --- & 65.7 & 13 & 72.2 & 62 & --- & --- \\
\hline Védrantais & France & 45.9 & 30 & 70.5 & 23 & 61.9 & 28 & 71.9 & 7 \\
\hline Virgos & France & 37.5 & 12 & --- & --- & --- & --- & --- & --- \\
\hline WMR 29 & United States & 49.2 & 64 & --- & --- & --- & --- & --- & --- \\
\hline Zunesco & France & --- & --- & 53.7 & 12 & 53.9 & 21 & --- & --- \\
\hline
\end{tabular}


a weak correlation between number of adults and number of larvae. For example, in 98-2, 'Fegouss 1' and B66-5 had similar scores for adults (70.5/100 and 71.8/100), but very different scores for larvae (26.1/87 and 84.6/87). Therefore, both adults and larvae populations must be considered to properly evaluate resistance.

The genotype effects were significant for differences in adult populations (Kruskal and Wallis test, $P<0.01$ ). The genotype effects were significant for differences in larvae populations in 97-2, 98-1, and 98-2 trials (Kruskal and Wallis test, $P<0.001$ ), but not in the 99 trial (Kruskal and Wallis test, $P=0.53$ ). Because of other pest problems (melonworms and downy mildew), the latter trial was stopped 7 weeks after transplanting, thus only two countings of larvae were available. A low B. tabaci infestation level and too few observations may explain this lack of significance. Based on adults and larvae average ranking when genotype effects were significant, both highly susceptible and resistant genotypes were identified.

The average rankings of the genotypes were given for adults and larvae during low infestation (Table 1) and during high infestation (Table 2). Data for larvae in 99 were omitted because the genotype effect was nonsignificant. The Charentais type cultivar 'Védrantais' was present in each of the trials and was among the most susceptible genotypes. Some genotypes were more susceptible than 'Védrantais'. Adults were attracted by 'Ouzbèque-1' (Table 1), 'Délice de table', and 'AR Top Mark' (Table 2 ). We observed the greatest number of larvae on 'Durgapura Madhu 1'under low infestation (Table 1), and on PI 172812, PI 183307, and B66-5 under high pressure (Table 2). Eleven genotypes were observed in several trials and at least once under high infestation (in bold, Tables 1 and 2). Among those genotypes, few adults or few larvae were observed on seven of them: PI 161375,PI 164723, PI414723,90625, Faizabadi Phoont, Kanro Makuwa, and Meloncillo. Three Indian genotypes, PI 414723, PI 164723, and 90625, and a Korean accession PI 161375 appeared partially resistant to B. tabaci-they had a low attractiveness for adults and were a low source of secondary infestation (few larvae under leaves) whatever the infestation pressure. We observed four to six times fewer adults on those genotypes than on 'AR Top Mark' or 'Délice de Table'. The larvae were 10 to 30 times less numerous on the partially resistant genotypes than on 'AR Top Mark' and B66-5.

No observations on resistance to $B$. tabaci in PI 164723 and PI 161375 have been published. McCreight (1992) observed the accession 90625 under very heavy infestations of B. tabaci in California. It had the highest level of plant vigor up to 4 weeks after planting, but was very weak after 8 weeks. Bois- sot et al. (2000) studied 90625 resistance using controlled infestation by 30 females. They observed a high rate of larval mortality (74\%) compared to 'Védrantais' (23\%). This antibiosis may partially explain the field resistance we observed. It may not be sufficient to overcome the heavy infestation levels that occur in California or elsewhere. PI 414723 was more heavily attacked by $B$. tabaci A-biotype than was WMR 29 under heavy infestation in California (Kishabaa et al., 1992). In Guadeloupe, we observed four times more adults in WMR 29 than on PI 414723. This might indicate that resistance to $\mathrm{A}$ and B biotypes of B. tabaci is different in C. melo. 'Kanro Makuwa' was previously observed resistant to B. tabaci biotype B in Spain. We observed few adults on that genotype (Tables 1 and 2), but its ranking was intermediate for larvae.

Since Painter's proposition (Painter 1951), three types of insect resistance have been considered. Antibiosis is an adverse effect of a plant on the biology of insects that fed on it. Antixenosis, associated with behavior, is reluctance or refusal to oviposit, eat or take shelter on a plant. Tolerance is the ability to recover from or withstand infestation. The field resistance to $B$. tabaci in PI414723, PI 161375, PI 164723, and 90625 may be antibiosis or antixenosis because the density of insects was affected. Field resistance was partial in

Table 2. Average ranking and maximum of number of B. tabaci observed on genotypes of C. melo in Guadeloupe [French West Indies] during high infestation. Ranking = average ranking of $\sum$ adults and $\sum$ larvae, $\mathrm{N}=$ number of observations, $\mathrm{df}=\mathrm{degree}$ of freedom, $\mathrm{KW}=\mathrm{Kruskal}$ and Wallis statistic for genotype effect; Max = maximum of adults observed under 2 leaves and larvae under 2.22- $\mathrm{cm}^{2}$ leaf disk. Each trial had 4 replicates.

\begin{tabular}{|c|c|c|c|c|c|c|c|c|c|}
\hline \multirow[b]{3}{*}{ Genotype } & \multirow[b]{3}{*}{ Source } & \multicolumn{4}{|c|}{$97-2$} & \multicolumn{4}{|c|}{$98-2$} \\
\hline & & \multicolumn{2}{|c|}{ Adults } & \multicolumn{2}{|c|}{ Larvae } & \multicolumn{2}{|c|}{ Adults } & \multicolumn{2}{|c|}{ Larvae } \\
\hline & & Ranking & Max & Ranking & Max & Ranking & Max & Ranking & Max \\
\hline & & \multicolumn{2}{|c|}{$\begin{array}{l}\mathrm{N}=30, \mathrm{df}=8 \\
\mathrm{KW} 23.8\end{array}$} & \multicolumn{2}{|c|}{$\begin{array}{l}\mathrm{N}=42, \mathrm{df}=10 \\
\mathrm{KW}=31.1\end{array}$} & \multicolumn{2}{|c|}{$\begin{array}{l}\mathrm{N}=100, \mathrm{df}=24 \\
\mathrm{KW}=60.4\end{array}$} & \multicolumn{2}{|c|}{$\begin{array}{l}\mathrm{N}=87, \mathrm{df}=23 \\
\mathrm{KW}=64.8\end{array}$} \\
\hline 90625 & PI 313970 & 18 & 5.9 & 6 & --- & --- & --- & --- & - \\
\hline Ananas d'Amérique & France & --- & -- & --- & --- & 43.5 & 40 & 56.5 & 91 \\
\hline Aodaisimouri & Japan & --- & --- & --- & --- & 28.5 & 33 & 27.5 & 20 \\
\hline AR Hale's Best Jumbo & United States & --- & --- & --- & --- & 51.4 & 68 & 50.8 & 58 \\
\hline AR Top mark & United States & 27 & 124 & 37 & 160 & --- & --- & --- & --- \\
\hline B66-5 & United States & --- & --- & --- & --- & 71.8 & 57 & 84.6 & 328 \\
\hline Brijucekustakaja & The Crimea & --- & --- & --- & --- & 54 & 48 & 30.6 & 38 \\
\hline Délice de Table & France & --- & --- & --- & --- & 92.1 & 114 & 64.4 & 219 \\
\hline Erokuin & Japan & --- & --- & --- & --- & 49 & 42 & 55.5 & 64 \\
\hline Faizabadi Phoont & India & 14 & 27 & 12.7 & 32 & --- & --- & --- & --- \\
\hline Fegouss1 & --- & --- & --- & --- & --- & 70.5 & 145 & 26.1 & 21 \\
\hline Hammershog Friland & Sweden & --- & --- & --- & --- & 63.8 & 59 & 42.3 & 50 \\
\hline Iran B & Iran & --- & --- & --- & --- & 85.3 & 107 & & \\
\hline Kanro Makuwa & Japan & 3.9 & 10 & 18 & 14 & 9.9 & 15 & 26 & 24 \\
\hline Kogane 9 Go Makuwa & Japan & --- & --- & --- & --- & 32.6 & 25 & 24.9 & 16 \\
\hline Kolajsan & Asia & --- & --- & --- & --- & 73 & 52 & 60.3 & 54 \\
\hline Kroumir & France & --- & --- & --- & --- & 34.4 & 30 & 55.5 & 41 \\
\hline Malaga & Spain & --- & 53 & 33.3 & 56 & --- & --- & --- & --- \\
\hline Meloncillo & Colombia & 17.1 & 43 & 12.1 & 13 & 13 & 17 & 18.1 & 24 \\
\hline Miel Blanc & China & 11 & 19 & 19 & 21 & --- & --- & --- & --- \\
\hline PI 161375 & Korea & --- & --- & --- & & 42.3 & 44 & 11 & 14 \\
\hline PI 163208 & India & 24 & 33 & 29.5 & 97 & --- & --- & --- & --- \\
\hline PI 164723 & India & 5.8 & 19 & 9.5 & 14 & 19.9 & 32 & 8.6 & 11 \\
\hline PI 164797 & India & --- & --- & --- & --- & 33.9 & 37 & 38.8 & 78 \\
\hline PI 164821 & India & --- & --- & --- & --- & 80.9 & 61 & 50.3 & 39 \\
\hline PI 172812 & Turkey & --- & --- & --- & --- & 78.9 & 77 & 76.1 & 209 \\
\hline PI 179905 & India & --- & --- & --- & --- & 27.1 & 46 & 41.1 & 48 \\
\hline PI 183307 & India & --- & --- & --- & --- & 60.9 & 100 & 76.8 & 114 \\
\hline PI 414723 & India & --- & --- & --- & --- & 27.3 & 40 & 15.1 & 22 \\
\hline Shiroubi Okayama & Japan & 15.4 & 28 & 24.7 & 41 & --- & --- & --- & --- \\
\hline V0001 & --- & --- & --- & --- & --- & 56.6 & 56 & 56.9 & 71 \\
\hline Védrantais & France & 25.7 & 42 & 35.5 & 138 & 62.3 & 71 & 62.3 & 92 \\
\hline
\end{tabular}


those genotypes, and its level may be high enough to significantly reduce pesticide use for whitefly control. To build higher levels of resistance by combining different genes, a better understanding of the genetic control of the resistance in those genotypes is needed. Because counting adults and larvae in field trials is highly time consuming and because the genotypes needed to be observed at least twice, this method of measuring resistance cannot be used for genetic analyses or breeding programs. The next step of this study will be to develop bioassays to measure the resistance levels and their component (antibiosis or antixenosis).

Other insect resistances have been described in PI 161375, PI 414723, and 90625. PI 161375 and PI 414723 are known for their resistance (antibiosis, antixenosis, tolerance to leaf curling) to the melon aphid, Aphis gossypii (Bohn et al., 1972; Kishaba et al., 1971; Lecoq et al, 1979; Pitrat and Lecoq, 1980). Both have been used for genetic resistance studies (Bohn et al., 1973; Kishaba, et al 1976; Pitrat, 1991; Pitrat and Lecoq, 1982). 90625 is tolerant to leaf curling caused by the melon aphid (Bohn et al., 1996) and expressed antixenosis against this aphid (Boissot et al., 2000). It is also is partially resistant to melonworm (Guillaume and Boissot, 2001). Those three genotypes should be studied to further understand insect resistance in C. melo.

\section{Literature Cited}

Bird, J. 1998. History of Bemisia tabaci as a pest in Puerto Rico. p. 1. In: Proc. 2nd Intl. Wkshp. on Bemisia and geminiviral diseases, San Juan, Puerto Rico, 7-12 June 1998.

Bird, J. and J.K. Brown. 1998. Displacement of the sida race of Bemisia tabaci by the B biotype of the B. tabaci complex in Puerto Rico. p. 20. In: Proc. 2nd Intl. Wkshp. on Bemisia and geminiviral diseases, San Juan, Puerto Rico, 7-12 June 1998

Bohn G.W.,A.N. Kishaba and J.D. McCreight 1996. A survey of tolerance to Aphis gossypii Glover in part of the world collection of Cucumis melo L. In: Proc. Cucurbits towards 2000, VIth Eucarpia Mtg. on Cucurbit Genetics and Breeding, Malaga, Spain, 28-30 May 1996.
Bohn, G.W., A.N. Kishaba, J.A. Principe, and H.H. Toba. 1973. Tolerance to melon aphid in Cucumis melo L. J. Amer. Soc. Hort. Sci. 98:37-40.

Bohn, G.W., A.N. Kishaba, and H.H. Toba. 1972. Mechanisms of resistance to melon aphid in a muskmelon line. HortScience 7:281-282.

Boissot, N., C. Pavis, R. Guillaume, D. Lafortune, and N. Sauvion. 2000. Insect resistance in Cucumis melo accession 90625. Acta Hort. 510:297-304.

Brown, S., W. McLaughling, R. Cabarello, and J. Brown. 1998. Characterization, distribution, and host plants of whiteflies in Jamaica. p. 19. In: Proc. 2nd Intl. Wkshp. on Bemisia and geminiviral diseases, San Juan, Puerto Rico, 7-12 June 1998.

Etienne, J., J.B. Quiot, and L.M. Russel. 1991. Les aleyrodidae en Guadeloupe, cas de $B e$ misia tabaci. p. 85-91. In: Proc. Rencontres Caraïbes en lutte biologique, Guadeloupe, 5-7 Nov. 1990.

Guillaume, R. and N. Boissot. 2001. Resistance to Diaphania hyalinata L. (Lepidoptera: Crambidae) in Cucumis Species. J. Econ. Entomol. 94(3):719-723.

Kishaba, A.N., G.W. Bohn, and H.H. Toba. 1976. Genetic aspects of antibiosis to Aphis gossypii in Cucumis melo from India. J.Amer. Soc. Hort. Sci. 101(5):557-561.

Kishaba, A.N., G.W. Bohn, and H.H. Toba. 1971. Resistance to Aphis gossypii in muskmelon. J. Econ. Entomol. 64(4):935-937.

Kishaba, A.N., S. Castle, J.D. McCreight, and P.R. Desjardins. 1992. Resistance of white-flowered gourd to sweetpotato whitefly. HortScience 27(11):1217-1221.

Lecoq, H., S. Cohen, M. Pitrat, and G. Labonne. 1979. Resistance to cucumber mosaic virus transmission by aphids in Cucumis melo. Phytopathol. 69(12):1223-1225.

McCreight, J. 1992. Preliminary screening of melons for sweetpotato whitefly resistance. Cucurbit Genet. Coop. Rpt. 15:59-61.

McCreight, J. 1993. Screening of melons for sweetpotato whitefly resistance: 1992 . Cucurbit Genet. Coop. Rpt. 16:49-52.

McCreight, J. 1994. Screening of melons for sweetpotato whitefly resistance: 1993 . Cucurbit Genet. Coop. Rpt. 17:83-85.

McCreight, J. 1995. Screening of melons for silverleaf whitefly resistance: 1994 . Cucurbit Genet. Coop. Rpt. 18:45-47.

Moreno, V., J.L. Gomez Aguilera, C. Guerau De
Arellano, and L.A. Roig. 1993. Preliminary screening of cucurbits species for Bemisia tabaci Genn. whitefly resistance. Cucurbit Genet. Coop. Rpt. 16:87-89.

Painter, R.H. 1951. Insect resistance in crop plants. Macmillan, New York.

Paul, C. 1999. CIPMNET 1999, Annual review and planning meeting (ATM).Summary report. Procicaribe-CARDI, St Augustine, Trinidad \& Tobago.

Pitrat, M. 1991. Linkage groups in Cucumis melo L. J. Heredity 82:406-411.

Pitrat, M. and H. Lecoq. 1980. Inheritance of resistance to cucumber mosaic virus transmission by Aphis gossypii in Cucumis melo. Phytopathol. 70:958-961.

Pitrat, M. and H. Lecoq. 1982. Relations génétiques entre les résistances par non-acceptation et par antibiose du melon à Aphis gossypii. Recherche de liaisons avec d'autres gènes. Agronomie 2(6): 503-508.

Riley, D.G. and J.C. Palumbo. 1995. Action thresholds for Bemisia argentifolii (Homoptera: Aleyrodidae) in cantaloupe. J. Econ. Entomol. 88(6):1733-1738.

Sauvion, N., C. Pavis, A. Huc, M. Rousseau, and N. Boissot. 1998. Caractérisation de Bemisia tabaci Gennadius biotype B (Hemiptera: Aleyrodidae) en Guadeloupe. Annales Soc. Entomol. France 35 (Supplément):46-53.

Sauvion, N., C. Pavis, A. Huc, M. Rousseau, G. Delvare, F.J. Morales, and N. Boissot. 2000. Bemisia tabaci biotype B (Hemiptera: Aleyrodidae) and its parasitoids: Guadeloupe island as a representative site of the Caribbean. p. 416. In: Proc. XXI Intl .Cong. of Entomol. Iguassu Falls, Brazil, 20-26 Aug. 2000.

Simmons, A.M. and J.D. McCreight. 1996. Evaluation of melon for resistance to Bemisia argentifolii (Homoptera: Aleyrodidae). J. Econ. Entomol. 89(6): 1663-1668.

Soria, C., A.I.Lopez-Sese, and M.L. Gomez-Guillamon. 1999. Resistance of Cucumis melo against Bemisia tabaci (Homoptera: Aleyrodidae). Environ. Entomol. 28(5):831-835.

SPSS. 1998. Systat: Statistics. Systat, Inc., Chicago.

Tappertzhofen, S. 1996. Population dynamics of Bemisia argentifolii in the south west of the Dominican Republic. Anz. Schadlingsk. Pflanz. Umwelt. 69(7):153-156.

Wiseman, B.R. 1994. Plant resistance to insects in integrated pest management. Plant Dis. 78: 927-932. 